\title{
THE WORD ABOUT THE NORTH CAUCASUS
}

\author{
(C) Yuri A. Zhdanov
}

Yuri A. Zhdanov - doctor of chemistry, candidate of philosophical sciences, professor. Rector of the Rostov state university (1957-1988), Russian Federation.

Жданов Юрий Андреевич - доктор химических наук, кандидат философских наук, профрессор. Ректор Ростовского государственного университета (1957-1988 гг.), Российская Федерация.

The North Caucasus region is of the unique originality. It is the eternal bridge between the West and the East, between Europe and Asia. Its historical destinies and geopolitical traditions are rich in contradictory connections, cooperation and collisions of numerous cultures and peoples which are alive and which have been forgotten.

For the antique Greeks our edge was an eastern frontier of an Oecumene and a far outpost of culture of Hellenes among barbaric tribes. The memory of those times is kept by the ruins of Tanais, the Cimmerian Bosporus and Gorgippiya-Anapa.

The Silk Road was from the East through Ciscaucasia. The traditions of Buddhism are kept in the Kalmyks' national memory. Our region had become a northern boundary zone for the culture of Islam and Judaism. The spiritual traditions of Byzantium were spread through the Russian, Armenian and Georgian Orthodoxy.

In the North Caucasus, historical destinies and economic relations had connected peoples of Ukraine, Kazakhstan and Transcaucasia with a peculiar microcosm of our region. Russians and Ukrainians, mountain peoples, the representatives of the Armenian and Greek Diasporas made a unique contribution to the history of the national economy, life, culture and the public relations of the North Caucasus.

The Cossacks of Don, Kuban, Stavropol bring special cultural and historical originality into the life of the edge. Their mentality bears traditions of liberating fight, peasant wars, patriotic feats for the sake of the Fatherland in Asia, in the Balkans, in the years of the fight against Hitlerite invasion. They had created the remarkable monuments of folklore.

Our region put forward a mighty cohort of figures of culture and science whose creativity gained really global universal character. It is enough to remember the names of M. Sholokhov and A. Chekhov, the philosopher A. Losev, the sculptor Yevgeny Vuchetich, the artist A. Loktionov, the researcher of transuranium elements academician G. Flyorov, the Balkar academician geophysics M. Zalikhanov. The whole world had heard a penetrating muse of the Avarian poet Rasoul Gamzatov and Ossetian Costa Khetagurov. The son of Kabardian peoples Yu. Temerkanov directs the symphonic orchestra of St. Petersburg nowadays. The new genre that had won the audience of all the continents was created by the thinker in dance, Chechen Mahmoud Esambayev.

The traditions of the Nart sagas, the Old Iranian Avesta, the East Renaissance and the Kalmyk Jangar Epic had been in the national consciousness of the North Caucasus from the bottom of centuries. For the Russian culture, our edge had become a revelation and a source of inspiration in creative works of Griboyedov, Pushkin, Glinka, Lermontov, Tolstoy and Vereshchagin.

The most important and interesting issues of the region can be solved only with a help of active science invasion. Its growth in the North Caucasus had high rates. If till 1917 in all 
ISSN 2414-1143

Научный альманах стран Причерноморья. 2019. Том 17. № 1

Russia there were eleven thousand scientists, then now only in our region there are more than forty thousand of them. Scientific capacity of the North Caucasus developed in the last decade when in the region the "knowledge-intensive" industries (energy physics, tool engineering, radio electronics, chemical industry, etc.), the industries of agro-industrial complex began to develop intensively.

During this period in the territory of the region the network of the universities and political institutes extends, the North Caucasian scientific center of the higher school is created, the scientific institutions of Academy of Sciences of the USSR are sporadically formed. During the period from 1960 to 1980 on the growth rates of number of workers, the sphere of science and scientific service was ahead of all other branches of the national economy of the North Caucasus.

In the region, the real experience of cooperation of all edges, areas and national republics is accumulated. Without joint efforts of research and high school teams, it would be impossible to describe natural resources and productive forces of the region in the twelvevolume edition, it would be impossible to release "The history of peoples of the North Caucasus".

Now in the territory of the North-Caucasian economic region more than two hundred scientific institutions, including seventy-three industry research institutes, seventy branches of scientific research institute, laboratories, experimental stations, forty-six higher education institutions, eight scientific research institutes and forty-six scientific research laboratories, eight institutions of Russian Academy of Sciences function. Among them, there are one thousand and two hundred doctors of science and about fifteen thousand candidates of science. Ten members of the Russian Academy and over fifty industry academies work.

Now the separate institutions of Russian Academy of Sciences: the special astrophysical laboratory in Zelenchuk, the RATAN radio telescope, the neutrino station on Baksan, the helio-complex near Makhachkala, the branch of Institute of oceanology in Gelendzhik, the solar station near Kislovodsk, the geophysical center near Krasnodar, the academic laboratories in higher education institutions of Rostov, Stavropol, etc. work in our region.

The scientific capacity of the North Caucasus exceeds the academic centers of the Urals and the Far East in number.

The North Caucasus adjoins in the West to Ukraine, in the East to Kazakhstan, in the South to the Transcaucasian subcontinent. It gives rise to a set of common problems and spheres of cooperation. Researches of Donbass are general for us and for Ukrainians; the problems of Pre-Caspian concern both Kazakhs and us. Geomorphology, geology, hydrology and ecology of the Caucasus cannot be divided by hillsides: northern and southern. The Black Sea, the Azov Sea, the Caspian Sea and the Aral Sea are the relicts of one ancient ocean with the general regularities of tectonic processes, sedimentation and placement of natural resources.

In modern geopolitical conditions, the North Caucasus became one of the major if not the richest granary of Russia. Here almost everything is cultivated, from wheat, corn, buckwheat to tea and tangerines, all the directions of livestock production, plus fishery of the seas are presented. Possibilities of the development of processing industry, biotechnology, agricultural chemistry, modern selection in our region are immense.

It is hardly worth reminding that for Russia the North Caucasus remains the most important center of rest and treatment, as its recreational and balneological resources are unique.

It is especially necessary to note the fast rates of industrial development of our edge. The enterprises of metallurgy and mining, agricultural transport and atomic mechanical engineering, petro chemistry and chemical productions of radio electronics, optics, tool engineering, aviation and food industry demand permanent modernization on the basis of the latest scientific technologies; the intensive agro-industrial development of multinational edge creates the mass of scientific problems in the sphere of economy, the placement of produc- 
Научный альманах стран Причерноморья. 2019. Том 17. № 1 tive forces and the social relations. The culture problems look unique in their originality. The field of activity for science in the North Caucasus is boundless.

The science should broaden the sphere of complex studying of natural resources and productive forces of the region (the ecology of diverse climatic zones, from arid to highlands and subtropics; the researches of destiny and efficiency of the southern seas; the energy resources of the edge: coal, oil and gas, hydropower, nuclear power, solar energy and wind power).

It is necessary to develop a complex of humanitarian researches to deepen the studying of history, culture, ethnography of the numerous peoples of the region, traditions of the Cossacks and also of peoples of Diasporas (Armenians, Jews, Greeks, Bulgarians, etc.), to revive oriental studies and Caucasus studies and the studying of the international relations. The creation of Economic Association of the North Caucasus will demand attention to the problems of economy, investment, transport, intraregional and interregional communications.

The big complex of problems arises in the sphere of fundamental researches. Among them there is an informatization of social production, economy, life, scientific researches; development of modern methods of radio electronics and microprocessor equipment. It is also important to solve the problems of modern physics, in particular, of a solid body, superconductivity, astrophysics, radiology and methods of applied mathematics and mechanics for the solution of problems of mechanical engineering and automation. The works in the field of thin chemical organic and inorganic synthesis, in the field of receiving new materials and biotechnologies for the food, medical industry and livestock production will be continued; the methods of modern biology for selection, genetic engineering, agricultural chemistry and melioration need development.

The in-depth study of mineral resources of the North Caucasus and the Western PreCaspian for mining (coal, salts and polymetals) has to be continued. The improvement of energy complex and usage of nonconventional types of energy: solar power engineering, wind power, underground heat, energy of the small rivers is important. The complex ecological researches on the basis of modern analytical methods and system mathematical modeling are coming. The country is interested in the development of a recreational complex of the South of Russia: balneology, tourism and economy.

In the sphere of humanitarian and social sciences the studying of problems of history and archeology of the region, ethnography and the national relations, social psychology, linguistics and philology, economy, the theory and cultural history is necessary. The revival of the Russian oriental studies focused both on internal and on external problems (Iran studies, Arab studies, Turkology, Caucasus studies), the studies of religious traditions of Christianity, Islam, Buddhism and Judaism are the most important tasks for the region.

The science can work in the North Caucasus region successfully only on condition of close cooperation with science of Ukraine, Kazakhstan, Georgia, Armenia and Azerbaijan in the solution of common problems. Our edge is big and extensive. It opens possibilities for wide initiatives, creative application of mind and energy.

Опубликовано на русском языке в издании: Юг России. Справочные материалы. Ростов-наДону. 1993. С. 3-7.

На английском языке публикуется впервые.

The article is published in Russian in the edition: The South of Russia. Reference materials. Rostov-onDon. 1993. pp. 3-7.

In English, it is published for the first time.

6 February, 2019 